\title{
Managing Thrips and Tomato Spotted Wilt in Pepper ${ }^{1}$
}

\author{
Joe Funderburk, Steve Olson, Julianne Stavisky, and Yolanda Avila²
}

Thrips are serious pests of ornamental, vegetable, and fruit crops in the field and greenhouse. Feeding and egg-laying by thrips results in distortion, discoloration, silvering, and bronzing of leaves and fruits of vegetables reducing their market value. Some species of thrips are vectors of bunyaviruses (family Bunyaviridae, genus Tospovirus, type species Tomato spotted wilt). Severe epidemics occur annually on food, fiber, and ornamental crops in temperate, subtropical and tropical regions of the world.

The western flower thrips (Frankliniella occidentalis) was spread nearly worldwide over the past two decades. This species, which is native to the southwestern US, was first noted in Florida in 1985 (Salguero Navas et al. 1991). It is usually considered the most efficient vector of tomato spotted wilt, and the disease was first noted in Florida in 1986 (McRitchie 1986). Epidemics occur annually on vegetable and agronomic crops in north Florida and Georgia, and epidemics occasionally occur in central and southern Florida. Another important vector responsible for epidemics of the disease is the tobacco thrips (Frankliniella fusca). This species is native to the region. Other thrips species that are known vectors in other parts of the world occur in Florida, including the Florida flower thrips (Frankliniella bispinosa), the onion thrips (Thrips tabaci), and the common blossom thrips (Frankliniella schultzei).

\section{Flower Thrips Biology and Ecology}

Many of the thrips species common in Florida reproduce in pepper. The Florida flower thrips and melon thrips (Thrips palmi) are common in southern Florida. The only species common on pepper in central Florida is the Florida flower thrips. Species abundant in northern Florida are the western flower thrips, the eastern flower thrips (Frankliniella tritici), and the Florida flower thrips. Adults and larvae of the melon thrips damage leaves, flowers, and small fruit. The biology and economic importance of flower thrips species in Florida are described in Funderburk and Stavisky (2004).

The western flower thrips, the eastern flower thrips, and the Florida flower thrips aggregate in the flowers with the larvae feeding on the flowers and

1. This document is ENY-658, one of a series of the Entomology and Nematology Department, Florida Cooperative Extension Service, Institute of Food and Agricultural Sciences, University of Florida. Date printed: March 2004. Please visit the EDIS Web site at http://edis.ifas.ufl.edu. More information is available at http://thrips.ifas.ufl.edu.

2. Joe Funderburk, professor, Entomology and Nematology Department; Steve Olson, professor, Horticulture Department; Julianne Stavisky, senior biological scientist, North Florida REC, Quincy, Florida; Yolanda Avila, graduate research assistant, Entomology and Nematology Department, Gainesville. Cooperative Extension Service, Institute of Food and Agricultural Sciences, University of Florida, Gainesville, 32611.

In this publication, the specific use of trade names is solely for the purpose of providing specific information. It is not a guarantee or warranty of products named and does not signify that they are approved to the exclusion of others of suitable composition.

The Institute of Food and Agricultural Sciences (IFAS) is an Equal Employment Opportunity - Affirmative Action Employer authorized to provide research, educational information and other services only to individuals and institutions that function without regard to race, creed, color, religion, age, disability, sex, sexual orientation, marital status, national origin, political opinions or affiliations. For information on obtaining other extension publications, contact your county Cooperative Extension Service office. Florida Cooperative Extension Service / Institute of Food and Agricultural Sciences / University of Florida / Larry R. Arrington, Interim Dean 
small fruits. Figure 1 shows that three species of thrips are common in northern Florida; whereas, only one species is common in central Florida.

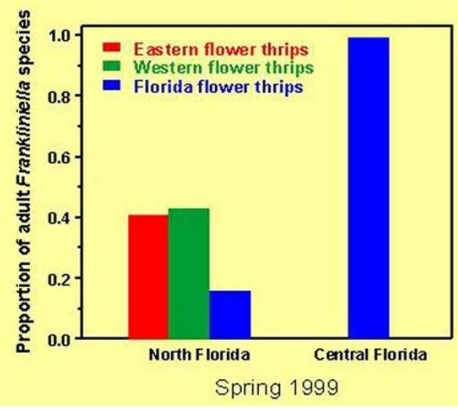

Figure 1. The proportion of thrips species inhabiting pepper flowers in central and northern Florida.

Flower thrips have a high reproductive potential. Population characteristics include feeding on a wide range of plant hosts, an ability to disperse rapidly, a short generation time, and parthenogenesis, which is the ability to produce offspring without mating. These population attributes allow thrips to exploit a growing crop and they have become the key pest problems faced by growers in northern Florida, Georgia, and other parts of the Southeast USA. Attempts to manage populations with conventional pest management methods such as chemical insecticides have not been effective. Populations of thrips may continue to increase despite frequent applications of toxic insecticides. Insecticides that are toxic to a broad spectrum of insect species suppress populations of natural enemies thereby increasing losses from secondary insect pests. Attempts to control populations of thrips by regular applications of insecticides have led to the development of resistance to most classes of insecticides (Immaraju et al. 1992). Furthermore, insecticidal control of thrips is not effective in preventing the spread of tomato spotted wilt because the insecticides do not kill quickly enough to prevent disease transmission by colonizing adults.

The life stages of thrips include an egg, larva I, larva II, pupa I, pupa II, and adult. Developmental times of egg, larvae, and pupae are about 6, 5, and 5 days, respectively, for each species. The adults of all species feed on pollen which increases longevity and the number of eggs produced (Tsai et al. 1995; Tsai et al. 1996).
Development of thrips is slow at cool temperatures. The minimal temperature required is about $10^{\circ}$ centigrade. About 30 to 40 days are necessary for a complete generation during the winter in the southern US. Generations develop more rapidly as the temperatures increase in the spring, and populations of flower thrips become very abundant in the near absence of natural enemies developing on the abundant plant hosts (Toapanta et al. 1996). Population numbers decline greatly in the summer and fall as natural enemies become important factors affecting their abundance (Chellemi et al. 1994). In southern Florida, conditions are optimal during the winter. Populations of melon thrips are greatest during late winter/early spring.

The plant species serving as reproductive hosts vary with each individual species of thrips. Adults commonly feed in the flowers of plants that are not reproductive hosts. Adults of the western flower thrips, the eastern flower thrips, and the Florida flower thrips were collected in the flowers of most of the 37 plant species sampled in a survey conducted in northern Florida (Chellemi et al. 1994).

The minute pirate bugs (Family Anthocoridae) are the most important predators of thrips that have been identified (Funderburk et al. 2000). Species of anthocorids occur nearly worldwide. The species in the southern US is the insidious flower bug (Orius insidiosus), with Orius pumilio also occurring with the insidious flower bug in southern Florida. Other thrips predators include bigeyed bugs (Family Geocoridae), damsel bugs (Family Nabidae), lacewings (Family Chysopidae), predatory thrips (primarily in the Family Aeolothripidae), and predatory mites (Family Phytoseiidae). Several parasites attack thrips. Species of parasitic nematodes (Family Allantonematidae) are important parasites of certain thrips species in the southern US.

\section{Tomato Spotted Wilt}

The tomato spotted wilt virus is circulative and replicative, in which the cycle of virus acquisition and transmission begins with larval feeding of infected plant tissue. The virus passes through the midgut of the insect and is spread to various cells and organs, including the salivary glands. It is in the salivary 
glands that the virus is able to replicate. The virus is transmitted to an unifected plant when the saliva is injected into the plant tissue during feeding.

In crop systems, the virus is transmitted by the adult thrips. Importantly, adult thrips that have not acquired the virus as larvae are not able to transmit the virus. This is due to a barrier in the midgut of the adult thrips, in which the viral particles cannot pass.

Only certain species of thrips are able to transmit tomato spotted wilt virus. No other insects such as aphids or whiteflies are vectors. At least seven species of thrips are vectors of tomato spotted wilt virus (Sherwood et al. 2000).

The tomato spotted wilt virus has a worldwide distribution, with a plant host range of over 926 species. Most susceptible plant species belong either to the Compositae family, of which 213 species are susceptible, or the Solanaceae family, of which 168 species are susceptible. More detailed information on the biological and molecular aspects of the tomato spotted wilt virus, including a list of host plants, can be found at the URL, http://www.dpw.wageningen-ur.nl/viro/research/ tospo.html.

Epidemics of tomato spotted wilt occur in many geographic regions worldwide. The severity and timing of epidemics in a particular cropping system are the result of interactions between the thrips vector, the pathogen host plant, and the pathogen. Tomato spotted wilt virus has been found to infect plant species of natural vegetation that are found growing close to susceptible crops, and in some situations natural vegetation is an important source of viruliferous adult thrips that transmit to susceptible crops (Peters 1998). In other situations, susceptible crops are the source of viruliferous adults invading new fields.

\section{Managing Thrips and Tomato Spotted Wilt in Peppers}

The adults of western flower thrips, eastern flower thrips, melon thrips, and Florida flower thrips aggregate in the flowers of pepper where they feed on pollen and the petals, pistils, and the stamens. Economic thresholds have not been established, however it is known that pepper tolerates 5 to 10 adults per flower without serious damage. Each of the species lays eggs in the flower with the larvae developing in the flowers and on the small fruits. Again, economic thresholds have not been established. Peppers in northern Florida typically are exposed for a short period in the spring to populations of about 15 larvae per flower without economic damage. Longer exposure to greater populations has been observed to result in serious fruit damage.

Thrips in the flowers and small fruit are sampled by sharply thumping the flowers onto a white cardboard or plate. Adults and larvae are stunned temporarily for counting. Magnification of $25 \mathrm{X}$ or more is needed to deterine the individual species of adults preserved in 60-70\% ethyl alcohol.

Thrips in peppers in the southern US are controlled naturally by minute pirate bugs. Calculating the predator to prey ratio when sampling provides a prediction of the effectiveness of the minute pirate bugs in controlling thrips (Funderburk et al., 2000). Under field conditions, about one predator to 180 thrips is needed for suppression of the populations of thrips. When the ratio reaches about one predator to 40 thrips, thrips populations will approach extinction within several days.

Populations of thrips develop rapidly on wild plants and crop hosts when temperatures increase in March and April. Minute pirate bugs are not active during the winter and early spring in north Floirda (Toapanta et al. 1996). Pepper fields serve as islands for aggregating populations in May (Figure 2). Thrips reproduce rapidly for about a week after the pepper plants first begin flowering (Ramachandran et al. 2001). Minute pirate bugs become active and they invade pepper in numbers sufficient to cause suppression of thrips. Populations of the predator persist for the remainder of the spring crop season feeding on pollen and the plants without economic damage. They prevent any recovery of the thrips populations. Although populations of the predator are less in the flowers of pepper during the fall crop, their numbers in proportion to the number of thrips are sufficient to prevent any population buildup (Figure 2). 


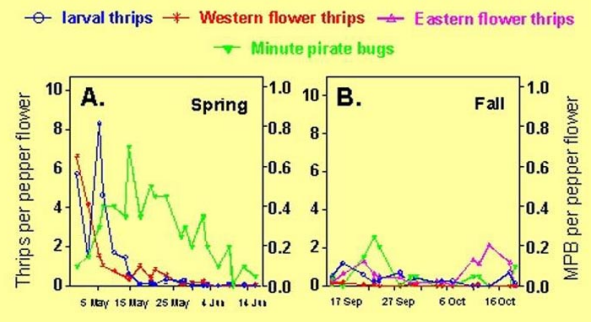

Figure 2. The population dynamics of thrips and the predator minute pirate bug in pepper.

Minute pirate bugs are active nearly year-round in central and southern Florida (Bottenberg et al. 2000). Population abundance may be low in December and January, otherwise their numbers are usually sufficient to prevent buildup of thrips populations in peppers.

The high reproductive capacity of thrips is a severe problem when attemping to suppress their populations with the use of insecticides.

Broad-spectrum insecticides (e.g. Danitol) are highly toxic to minute pirate bugs, and populations of thrips in the spring outstrip the toxic effects of weekly application of the insecticides (Figure 3). Insecticides can be selected that conserve populations of the minute pirate bug. Most lepidopterous pests can be controlled by spinosad (marketed as Spintor) and Bt-products (marketed under various trade names) that are not toxic to many natural enemies. Spintor is toxic to many species of thrips and is a good product that enhances the benefits of the predator by causing more rapid extinction of thrips (Figure 3).

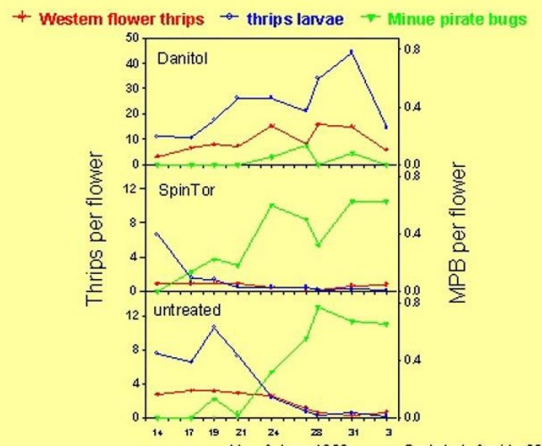

Figure 3. The effects of two insecticides on the population dynamics of thrips and the minute pirate bug.

Biological insecticides are not available to control populations of stink bugs, several species of which are occasional pests in pepper in the southern
US. However, pepper is not a preferred host, and economic problems are not usually oberved in Georgia and North Florida. Further, damaging populations occur late in the growing season when large fruit are present, and conservation of the minute pirate bug for thrips control is not critical.

Thrips are attracted to low UV blue, white, and yellow, and sight is the primary mechanism for locating flowers. UV-reflective mulches and other products are useful in confusing the colonizing adults. UV-reflective mulches are available commercially. Individual products vary in UV reflectance, and in the amount of insect control. Figure 4 compares the dynamics of thrips and minute pirate bugs on UV-reflective mulch versus traditional black plastic mulch in spring peppers in north Florida. The mulch in this study has a layer of metallic aluminum which reflects more than $75 \%$ of the UV light. The number of thrips is greatly reduced in the peppers grown on the UV-reflective mulch compared to the black mulch. However, colonization of the minute pirate bugs also is delayed and populations of thrips in the peppers on UV-reflective mulch are building as populations on black mulch are being suppressed. A seven to ten day delay in suppression and near extinction of thrips is typical.

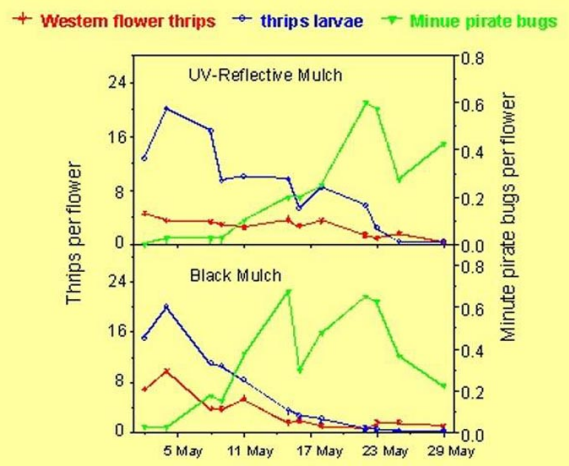

Figure 4. The effects of uv-reflective mulch on the population dynamics of thrips and the minute pirate bug.

A completely metallized UV-reflective mulch may not be suitable on early spring-planted peppers as soil temperatures are reduced 4 to $8^{\circ} \mathrm{F}$. To avoid yield loss due to low soil temperature, a five or six inch strip under the row of pepper plants should be left black. A completely metallized UV-reflective mulch is desirable for later plantings in the spring and fall when soil temperatures are optimal or above optimal. 
The first grower to adopt the biological control program was Tommy Smith of Thomas B. Smith Farms in Greensboro, Florida. He had experienced crop failure from thrips damage on previous occasions, despite making repeated applications of broad-spectrum insecticides. Spinosad was not labeled for use in peppers in the first year of implementation, and only Bt-products were used as insecticides (Figure 5).

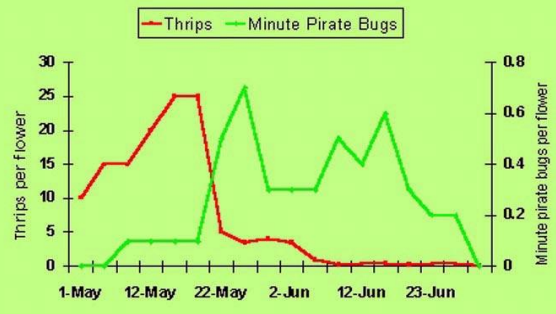

Figure 5. Population dynamics of thrips and minute pirate bugs in a commercial pepper field in 1997 (Courtesy Glades Crop Care, Inc.)

The next year spinosad and Bt-products were used (Figure 6).

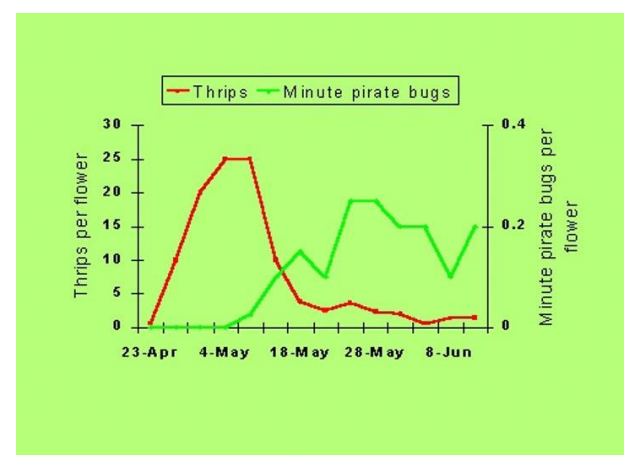

Figure 6. Population dynamics of thrips and minute pirate bugs in a commercial pepper field in 1998 (Courtesy Glades Crop Care, Inc.)

Other insect pest problems did not develop with the removal of the broad-spectrum insecticides. Data on the number of thrips and minute pirate bugs per flower were estimated twice weekly by a professional scout. Other growers in Florida and Georgia have since adopted the program. Although populations of thrips are high during early May in spring crops in north Florida and Georgia, the peppers set fruit and no fruit damage has occurred. Conversely, severe crop damage is reported by growers relying on calendar sprays of broad-spectrum insecticides. This management program that relies on biological control and reduced-risk insecticides such as Spintor has many economic benefits. These benefits include savings from reduced pesticide application, benefits from the conservation of other natural enemies such as lady bugs that control aphids and other pests, and the prevention of the potential of $100 \%$ fruit damage when minute pirate bugs are killed from application of broad-spectrum insecticides.

Minute pirate bugs are important in suppressing Florida flower thrips and melon thrips in central and southern Florida production areas (Bottenberg et al. 2000). Natural populations of minute pirate bugs integrated with selective use of insecticides constitutes the recommended program to manage melon thrips in pepper in Southeast Asia (Kajita et al. 1996). Experiments in Puerto Rico are revealing that minute pirate bugs occur in numbers sufficient to prevent population buildup of thrips in peppers. Repeated applications of broad-spectrum insecticides on vegetable crops in the Caribbean result in buildup of melon thrips problems (Etienne et al. 1990).

The benefits of biological control in preventing tomato spotted wilt incidence in pepper fields have been difficult to evaluate in field experiments. Epidemics have not developed in the pepper plots even when epidemics were occurring in nearby tomatoes. Minute pirate bugs are definitely very effective in predating on larval thrips and thereby preventing spread of the disease by the larvae in pepper. Predation is rapid, and we believe that there is a good possibility that minute pirate bugs prevent spread of the disease by the adults. Severe epidemics have been observed in fields where broad-spectrum insecticides were applied.

\section{References Cited}

Bottenberg, H., G. Frantz, and H. Mellinger. 1999. Refuge and cover crop plantings for beneficial insect habitats. Proceedings of the Florida State Horticultural Society 112: 339-341.

Chellemi, D.O., J.E. Funderburk, and D.W. Hall. 1994. Seasonal abundance of flower inhabiting Frankliniella species (Thysanoptera: Thripidae) on wild plant hosts.Environmental Entomology 23: 337-342. 
Etienne, J., J. Guyot, and X. van Waetermeulen. 1990. Effect of insecticides, predation, and precipitation on populations of Thrips palmi on aubergine (eggplant) in Guadeloupe.Florida Entomologist 73: 339-342.

Funderburk, J.E., J. Stavisky, and S.M. Olson. 2000. Predation of Frankliniella occidentalis (Thysanoptera: Thripidae) in field peppers by Orius insidiosus (Hemiptera: Anthocoridae). Environmental Entomology 29: 376-382.

Funderburk, J.E., and J. Stavisky. 2004. Biology and economic importance of flower thrips. Document EBY682. Florida Cooperative Extension Service, Institute of Food and Agricultural Sciences, University of Florida, Gainesville. 6pp.

Immaraju, J.A., T.D. Paine, J.A. Bethke, K.L. Robb, and J.P. Newman. 1992. Western flower thrips (Thysanoptera: Thripidae) resistance to insecticides in coastal California greenhouses. Journal of Economic Entomology 85: 9-14.

Kajita, H., Y. Hirose, M. Takagi, S. Okajima, B. Napompeth, and S. Buranapanichpan. 1996. Host plants and abundance of Thrips palmi Karny (Thusanoptera: Thripidae), an important pest of vegetables in southeast Asia. Applied Entomology and Zoology 31: 87-94.

Kucharek, T., L. Brown, F. Johnson, and J. Funderburk. 1990. Tomato spotted wilt virus of agronomic, vegetable, and ornamental crops. Florida Cooperative Extension Service, Plant Pathology Department circular 914, 10pp.

Peters, D. 1998. An updated list of plant species susceptible to tospoviruses, pp.107-110. In: Recent Progress in Tospovirus and Thrips Research. Proceedings of the Fourth International Symposium on Tospoviruses and Thrips in Floral and Vegetable Crops.Wageningen, The Netherlands.

Ramachandran, S., J.E. Funderburk, J. Stavisky, and S.M. Olson. 2001. Population abundance and movement of Frankliniella species and Orius insidiosus in field pepper. Agricultural and Forest Entomology 3: 129-137.
Salguero-Navas, V.E., J.E. Funderburk, R.J. Beshear, S.M. Olson, and T.P. Mack. 1991. Seasonal patterns of Frankliniella spp. (Thysanoptera: Thripidae) in tomato flowers. Journal of Economic Entomology. 84:1818-1822.

Sherwood, J.L., T.L. German, J.W. Moyer, D.E. Ullman. 2000. Tospoviruses.In Encyclopedia of Plant Pathology, ed. O.C. Moloy and T.D. Murray.John Wiley and Sons, Inc., New York, NY.

Toapanta, M., J.E. Funderburk, S. Webb, D.O. Chellemi, and J. Tsai. 1996. Abundance of Frankliniella spp. (Thysanoptera: Thripidae) on winter and spring host plants. Environmental Entomology 25: 793-800.

Tsai, J.H., B.Yue, S.E. Webb, J.E. Funderburk, and H.T. Hsu. 1995. Effects of host plant and temerature on growth and reproduction of Thrips palmi (Thysanoptera: Thripidae). Environmental Entomology 24: 1598-1603.

Tsai, J.H., B.S. Yue, J.E. Funderburk, and S.E. Webb. 1996. Effect of plant pollen on growth and reproduction of Frankliniella bispinosa.Acta Horticulturae 431: 535-541. 